\title{
Struktura przestrzenna i działowa przemysłu Polski na tle Unii Europejskiej w dwudziestolecie rozpoczęcia procesów transformacji systemowej
}

\section{WPROWADZENIE}

Zmiana systemu gospodarowania w Polsce, a także w innych krajach Europy Środkowo-Wschodniej, związana z wprowadzeniem mechanizmów gospodarki rynkowej, postawiła nowe wyzwania, wpłynęła na poszukiwanie nowych dróg rozwoju społeczno-gospodarczego tych krajów i doprowadziła do przekształcenia struktur gospodarczych. Proces transformacji systemowej pociąga za sobą zmiany w rozmieszczeniu i dostępności do poszczególnych czynników produkcji, różnych kategorii zasobów (surowcowych, kapitałowych, energetycznych, ludzkich, intelektualnych i in.), a także do miejsc zaopatrzenia surowcowo-materiałowego i rynków zbytu. Przemiany te zachodzą w warunkach budowy gospodarki opartej na wiedzy i przechodzenia od fazy industrialnej i postindustrialnej do fazy informacyjnej rozwoju cywilizacyjnego. Ich efektem jest przebudowa sektorowej struktury gospodarczej, w której działalność przemysłowa, będąca podstawową bazą ekonomiczną w fazie industrialnej, ustępuje działalności usługowej, w szczególności działalności związanej z oświatą, nauką i pracami badawczo-rozwojowymi. Konsekwencją tego procesu jest zmiana dotychczasowych struktur przestrzennych i działowych przemysłu oraz jego funkcji w rozwoju gospodarczym układów przestrzennych różnej skali, od układów lokalnych, przez regionalne po krajowe i międzynarodowe. W tej sytuacji zmieniające się warunki gospodarowania prowadzą do wzrostu zróżnicowań w poziomie rozwoju poszczególnych krajów i układów regionalnych. Ponadto, jak powszechnie wiadomo, działalność przemysłowa w większości krajów wysokorozwiniętych gospodarczo zmniejsza swoją funkcję w zakresie aktywizacji zasobów pracy, co jest konsekwencją mechanizacji, automatyzacji i komputeryzacji procesów produkcji. $\mathrm{Z}$ tej perspektywy istotne wydają się pytania o rolę, jaką będzie pełnił przemysł w Polsce w tej nowej fazie rozwoju cywilizacyjnego, jakie będzie generował efekty mnożnikowe rozwoju gospodarczego (por. Domański, Gwosdz 2008, Rachwał, Wiedermann 2008, Wiedermann 2007, 2008) oraz jakie będzie to miało odzwierciedlenie w przemianach różnorodnych struktur przestrzennych.

W świetle zarysowanych przesłanek celem pracy jest:

- analiza zmian roli przemysłu w gospodarce Polski w okresie transformacji gospodarczej i integracji europejskiej w oparciu o jego udział w strukturze zatrudnienia (pracujących) i wartości dodanej brutto na tle przemian w innych krajach UE; 
- określenie zmian struktury przestrzennej przemysłu Polski w układzie województw (w oparciu o mierniki pracujących i wartości dodanej brutto);

- ocena zmian w wydajności pracy w przemyśle wg województw, jako wyrazu nowoczesności przemysłu i konkurencyjności regionów w zakresie przyciagania inwestycji przemysłowych;

- analiza przemian struktury działowej przemysłu Polski na tle UE jako wyrazu procesów transformacyjnych (w oparciu o mierniki pracujących i produkcji sprzedanej), ze szczególnym uwzględnieniem zaawansowanych technologicznie działów przemysłu;

- analiza podobieństwa struktur działowych przemysłu Polski do krajów UE, w tym innych krajów transformujących swoje gospodarki.

Zakres przestrzenny pracy obejmuje Polskę w układzie województw (NUTS-2) oraz do celów porównawczych pozostałe kraje członkowskie UE. Analizy struktury przemysłu dokonano wg sekcji i działów PKD 2004 (NACE 1.1) obowiązującej do końca 2007 r., w świetle liczby pracujących, wartości dodanej brutto i produkcji sprzedanej przemysłu oraz obliczonego miernika syntetycznego (Zioło 1972, 1973). W celu określenia stopnia zróżnicowania działowego posłużono się wskaźnikiem zróżnicowania działowego Rodgersa, przy analizie podobieństwa struktury działowej wykorzystano metodę analizy skupień, natomiast do analizy struktury przestrzennej wykorzystano m.in. iloraz i współczynnik lokalizacji.

Zakres czasowy obejmuje lata 1995-2007 i w dużej mierze wynika z dostępności do porównywalnych danych dotyczących działalności przemysłowej w układzie nowych województw i państw UE. W przypadku niektórych krajów wystąpiły poważne bariery w dostępie do szczegółowych danych (m.in. brak lub konieczność wykorzystania danych za 2005/2006 i 2008 r. zamiast 2007 i 1996/1997 zamiast 1995; ze względu na tajemnicę statystyczną wystapiła także konieczność zgrupowania działów 15 i 16 oraz działów sekcji C w określonych przekrojach czasowych). Problem ten został omówiony szerzej we wcześniejszej pracy autora (Rachwał 2008).

Do celów porównawczych posłużono się wcześniejszymi badaniami dotyczącymi przemysłu regionów UE (Rachwał, Wiedermann, Kilar 2008a,b, 2009), zmian struktur działowych zatrudnienia (Rachwał 2010), efektów restrukturyzacji przedsiębiorstw przemysłowych (Rachwał 2006), procesów adaptacyjnych przemysłu Polski (Stryjakiewicz 1999, Domański 2003) oraz kształtowania się przemysłu wysokiej techniki w Polsce (Świdurska 2009), przemian polskiego przemysłu na tle krajów EŚW (m.in. Domański 2006, Rachwał 2009, van Zon 1996) i poziomu innowacyjności gospodarek krajów Europy (Gierańczyk 2009), przy czym w pracy ograniczono się do zaprezentowania najważniejszych wyników badań.

W analizie wykorzystano również bieżące informacje dotyczące kształtowania się procesów gospodarczych w warunkach trwającego ogólnoświatowego kryzysu. Należy jednak podkreślić, że upłynęło jeszcze zbyt mało czasu, aby dokonać kompleksowej oceny wpływu tego kryzysu na przemiany strukturalne przemysłu, gdyż, jak powszechnie wiadomo, ten sektor gospodarki cechuje się pewną „bezwładnością” struktury, wynikającą m.in. z kapitałochłonności i czasochłonności procesów inwestycyjnych, w efekcie czego nie należy oczekiwać dużych przekształcenia struktur działowych i przestrzennych przemysłu pod wpływem okresu dekoniunktury. 


\section{UwARUNKOWANIA PRZEMIAN PRZEMYSŁU w POLSCE}

Proces przemian struktury działowej zatrudnienia w przemyśle zachodzi pod wpływem różnorodnych uwarunkowań, które można podzielić na międzynarodowe i krajowe (Rachwał 2008). Impulsy płynące $\mathrm{z}$ otoczenia międzynarodowego związane są m.in. z procesami integracyjnymi państw i regionów (w tym ważnej z punktu widzenia Polski integracji europejskiej), koncentracją kapitału, wzrostem znaczenia korporacji międzynarodowych w gospodarce światowej i presji konkurencyjnej na rynku globalnym (por. Kilar 2009, Zioło 2009), zmianami w wielkości, kierunkach i motywach przepływów inwestycji zagranicznych, procesami delokalizacji i relokacji przedsiębiorstw w układzie globalnym, szybkim postępem technologicznym, szczególnie w dziedzinie technologii informacyjnej oraz automatyzacji i komputeryzacji procesów produkcji, rosnącą rolą wiedzy w gospodarowaniu, prowadzącą do wzrostu znaczenia zaawansowanych prac $\mathrm{B}+\mathrm{R}$ i innowacji, skróceniem cyklów życiowych produktów oraz zmianami modelu konsumpcji, gustów, nawyków i stylu życia członków „społeczeństwa informacyjnego”. Wśród nowych uwarunkowań, które uwidoczniły się w ostatnich dwóch latach (2008-2009), na uwagę zasługuje pogłębianie się światowego kryzysu gospodarczego i przedsięwzięcia rządów różnych krajów, a także instytucji Unii Europejskiej i innych organizacji międzynarodowych na rzecz przeciwdziałania skutkom społecznym i gospodarczym kryzysu.

W przypadku Polski i innych krajów będących w fazie transformacji systemowej, duże znaczenie mają uwarunkowania krajowe, wynikające ze zmian systemu gospodarowania, otwarcia rynku polskiego na napływ podmiotów zagranicznych, towarów i kapitału oraz realizowanej polityki gospodarczej państwa, przejawiającej się m.in. w kształtowaniu instrumentów prawnych ( $\mathrm{w}$ tym także harmonizowaniem prawa gospodarczego w związku z integracją z UE), charakterze prowadzonej polityki przemysłowej, w tym tempa, zakresu i ścieżek prywatyzacji przedsiębiorstw państwowych, tworzeniu specjalnych stref ekonomicznych oraz opracowywaniu i wdrażaniu strategii restrukturyzacji określonych sektorów przemysłu (Rachwał 2008). W szczególności należy zwrócić tu uwagę na przyjmowane w poszczególnych krajach Europy będących w fazie transformacji społeczno-gospodarczej różne strategie wdrażania reguł gospodarki rynkowej, na co wskazywało wielu autorów (m.in. Bożyk 1999, Balcerowicz 1997, Karpiński 2008, Kołodko 1999, Kornai 1997 , Koźmiński 1998, Rosati 1998, Wojtyna 1994). U progu procesu transformacji pojawiły się poważne dylematy, czy zastosowana w Polsce przez L. Balcerowicza tzw. terapia szokowa jest najlepszym rozwiązaniem, czy może należy raczej preferować działania ewolucyjne. Strategia wdrażania reguł gospodarki rynkowej była więc różnie oceniana przez ekonomistów (Łukawer 1994a, 1994b, Zioło 1996). Dyskusja ta trwa do dzisiaj, dlatego nawet po 20 latach od rozpoczęcia transformacji trudno o jednoznaczną ocenę wdrażanych programów przemian gospodarczych, niemniej jednak wpływ realizowanej polityki gospodarczej na tempo i zakres przemian przemysłu, w tym struktur zatrudnienia w poszczególnych krajach, jest bardzo duży. Do uwarunkowań krajowych należy zaliczyć także wprowadzenie nowych wymogów proekologicznych produkcji i konieczność przestrzegania ostrzejszych norm ochrony środowiska, a także politykę państwa w zakresie oświaty, nauki i wdrażania innowacji, szczególnie w odniesieniu do wymiany osiągnięć naukowo-badawczych, której znaczenie w warunkach budowy gospodarki opartej na wiedzy jest ogromne (Borowiec 2009, Borowiec, Dorocki, Jenner 2009, Gierańczyk 2009). 


\section{UDZIAŁ PRZEMYSŁU W ZATRUDNIENIU I WARTOŚCI DODANEJ BRUTTO}

Analiza zmian udziału przemysłu w latach 1995-2007 w strukturze zatrudnienia wskazuje na powolne, ale systematyczne zmniejszanie się roli tego sektora w aktywizacji zasobów pracy (ryc. 1). W latach 1995-2007 udział sektora przemysłu i budownictwa zmniejszył się z $31,2 \%$ do 29\%, a samego przemysłu (sekcje CDE wg PKD 2004) z 25,5\% do 23,1\%, przy czym należy zwrócić uwagę, że można wyróżnić tu dwie fazy przemian: w latach 1995-2001 dużego spadku udziału przemysłu w zatrudnieniu do 20,8\%, a następnie w latach 2002-2007 jego niewielkiego wzrostu. Wpływ na ten wzrost miało przeszacowanie danych dotyczących zatrudnienia w rolnictwie na podstawie Narodowego Spisu Powszechnego, co spowodowało skokowy wzrost udziału przemysłu w 2002 r.

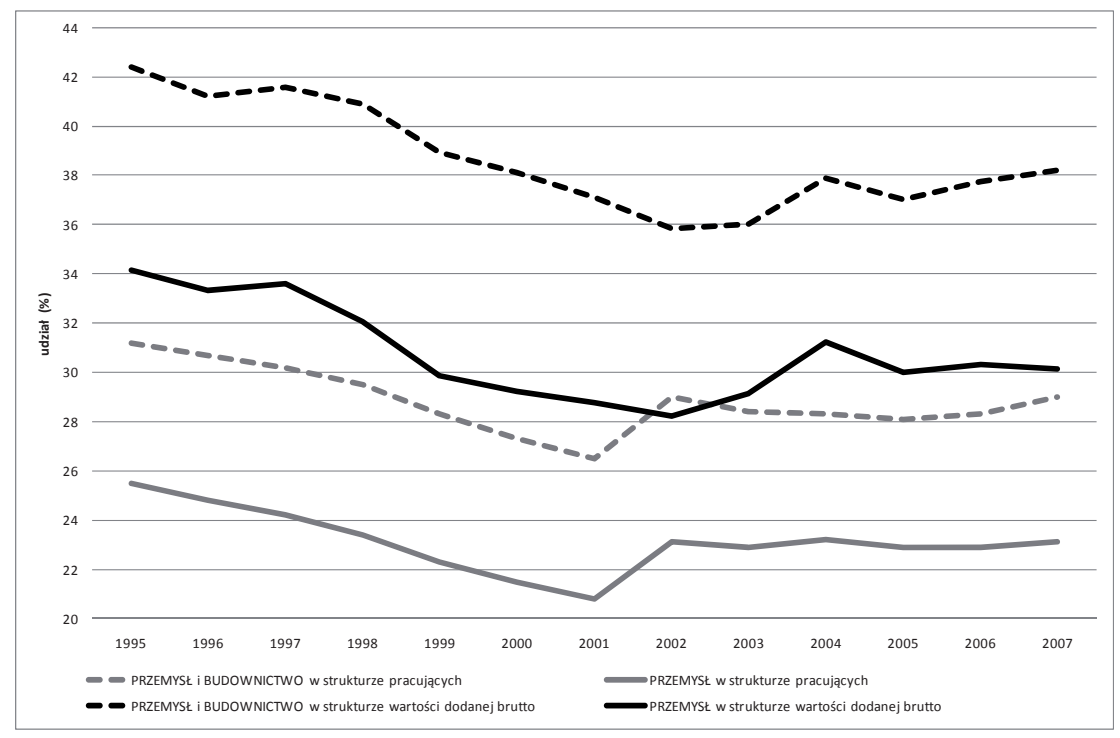

Ryc. 1. Udział przemysłu i budownictwa w strukturze pracujących i wartości dodanej brutto w Polsce w latach 1995-2007

Źródło: opracowanie własne na podstawie danych GUS

Analiza udziału przemysłu w strukturze wartości dodanej brutto wskazuje na jego dużo większą rolę w gospodarce pod względem ekonomicznym: udział przemysłu i budownictwa zmniejszył się z 42,4\% w 1995 r. do 38,2\% w 2007 r. (samego przemysłu odpowiednio z 34,2\% do 30,1\%), przy czym również zaobserwowano dwie fazy: spadku udziału do $2001 \mathrm{r}$. i jego wzrostu od $2002 \mathrm{r}$.

Stosunkowo niewielkie zmiany udziału przemysłu w badanym okresie sprawiły, że Polska pozostaje w grupie krajów Unii Europejskiej charakteryzujących się bardzo wysokimi udziałami sektora przemysłowego w zatrudnieniu w porównaniu ze „starymi” krajami UE-15 (ryc. 2) i wysokimi udziałami w wartości dodanej brutto (ryc. 3). 


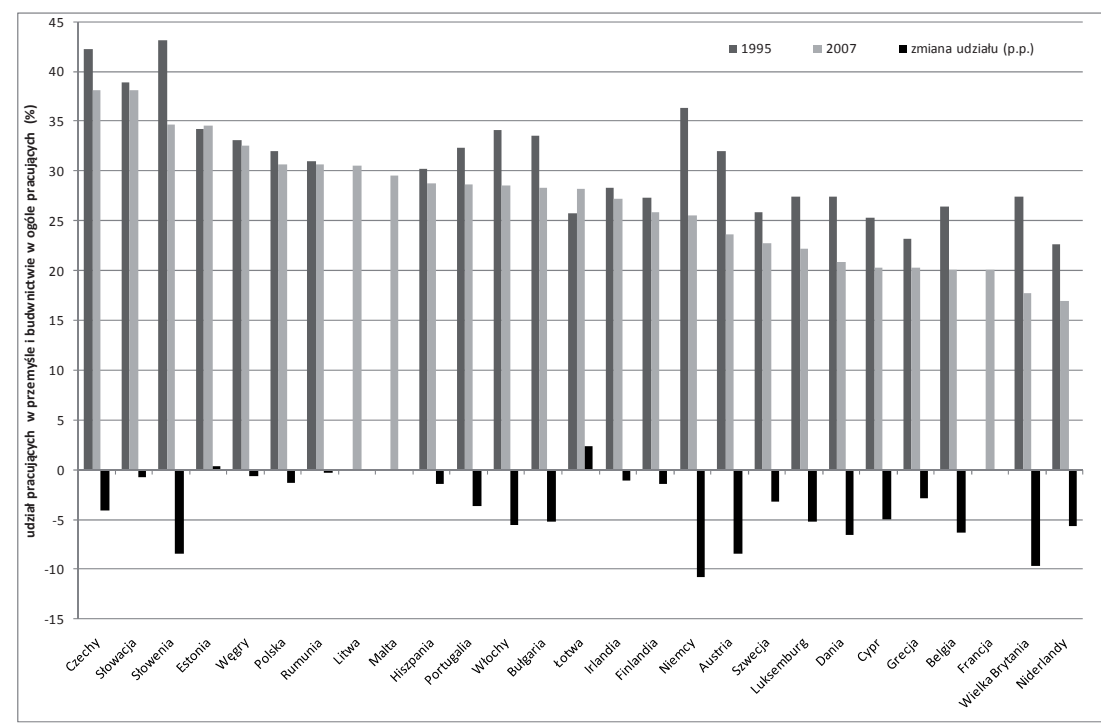

Ryc. 2. Udział przemysłu i budownictwa w strukturze pracujących w krajach Unii Europejskiej w 1995 i 2007 r.

Źródło: opracowanie własne na podstawie danych GUS

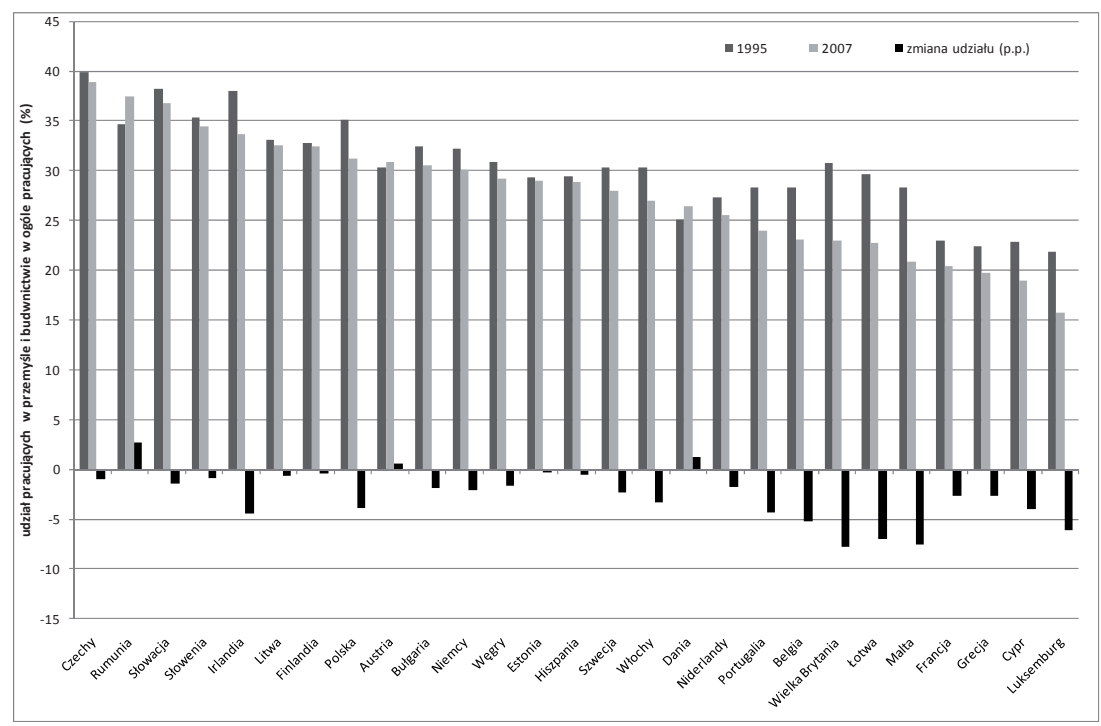

Ryc. 3. Udział przemysłu i budownictwa w wartości dodanej brutto w krajach Unii Europejskiej w roku 1995 i 2007 
Zjawisko wysokiego udziału przemysłu w zatrudnieniu jest charakterystyczne dla większości krajów Europy Środkowej i Wschodniej transformujących swoje gospodarki, które później wstąpiły do UE. Wynika to z faktu, że w krajach środkowo-wschodniej UE duże znaczenie mają przemysły tradycyjne, pracochłonne, a w krajach zachodnich UE dominują przemysły bardziej nowoczesne, w mniejszym stopniu aktywizujące zasoby pracy, ale cechujące się wysoką wartością dodaną brutto (ryc. 4).

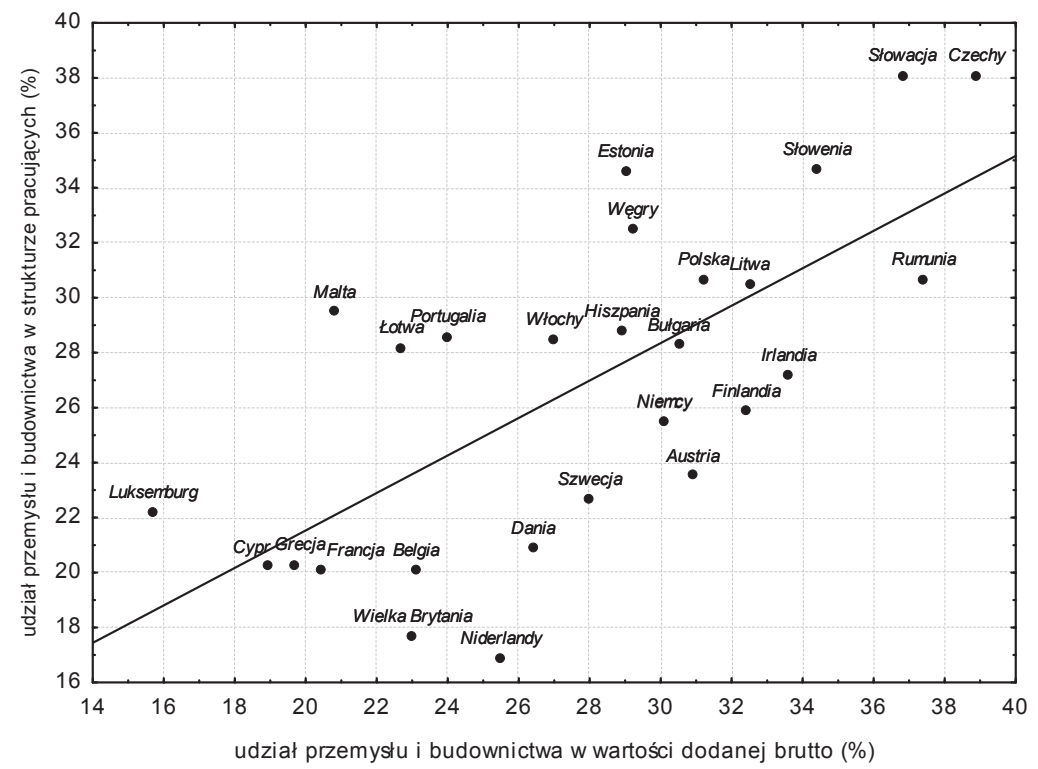

Ryc. 4. Zależność między udziałem przemysłu i budownictwa w wartości dodanej brutto a udziałem w strukturze pracujących w krajach Unii Europejskiej w 2007 r.

Źródło: opracowanie własne na podstawie danych GUS

Należy jednocześnie zwrócić uwagę, że największe spadki udziału przemysłu w zatrudnieniu i wartości dodanej brutto zanotowano w krajach mających już stosunkowo niskie wskaźniki udziału sektora przemysłowego w wartości tych mierników. Są to głównie kraje tzw. starej UE-15, w tym państwa rdzeniowe UE, takie jak Wielka Brytania. W krajach, które później wstąpiły do UE (w tym także Hiszpanii i Finlandii), spadek ten jest mniejszy.

Pomimo iż generalnie udział przemysłu w krajowych miernikach zatrudnienia i wartości dodanej brutto spada (choć nie we wszystkich krajach), co jest związane - w przypadku zatrudnienia - z mechanizacją produkcji i eliminacją pracy żywej w przemyśle, a także relokacją działalności do krajów nienależących do UE o niższych kosztach produkcji, to jednak w świetle wcześniejszych analiz w układzie regionalnym (Rachwał, Wiedermann, Kilar 2008a,b, 2009) należy stwierdzić, że w wielu regionach Europy, także tzw. starej Unii, udział ten jest wysoki i tylko nieznacznie maleje lub nadal rośnie. Wzrost udziału przemysłu w wartości dodanej brutto nie jest tak rzadkim zjawiskiem w regionach UE, jak można by się spodziewać i dotyczy np. wielu regionów Niemiec czy Austrii. Większość regionów o długich tradycjach i dużej roli przemysłu oraz regiony dynamicznie rozwijających się na 


\begin{tabular}{|c|c|c|c|c|c|c|c|c|c|c|c|c|c|c|c|c|c|c|c|}
\hline \multirow{4}{*}{ 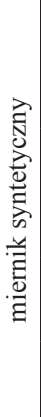 } & 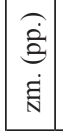 & 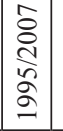 & $\hat{\sigma}$ & $\because$ & $\hat{i}_{1}^{m}$ & $\hat{n}$ & ?. & $\hat{i}^{m}$ & $\stackrel{\cong}{=}$ & $\begin{array}{l}0 \\
0 \\
0\end{array}$ & $\because$ & $\overrightarrow{0}$ & $\tilde{0}$ & $\begin{array}{l}\infty \\
\hat{\imath}\end{array}$ & $\vec{i}$ & $\stackrel{t}{\sigma}$ & $\stackrel{i}{i}$ & $\vec{i}$ & $\star$ \\
\hline & 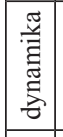 & \begin{tabular}{|l|}
8 \\
$\stackrel{1}{0}$ \\
2 \\
2 \\
2 \\
\end{tabular} & $\stackrel{0}{\stackrel{0}{=}}$ & $\overrightarrow{8}$ & $\vec{\Omega}$ & $\begin{array}{l}\hat{\sigma} \\
\varrho \\
=\end{array}$ & $\hat{a}$ & $\vec{\delta}$ & $\mid \begin{array}{l}n \\
\hat{0}\end{array}$ & $\begin{array}{c}0 \\
\infty \\
\infty\end{array}$ & $\hat{\alpha}$ & $\begin{array}{l}n \\
\stackrel{2}{0} \\
\varrho \\
0\end{array}$ & $\stackrel{m}{\stackrel{m}{=}}$ & $\hat{\dot{\infty}}$ & ڤి & $\underset{ٍ}{=}$ & $\stackrel{+}{\stackrel{\Xi}{\Xi}}$ & $\begin{array}{l}\text { भू } \\
\text { ŏ }\end{array}$ & $\begin{array}{l}0 \\
8 \\
8\end{array}$ \\
\hline & 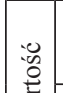 & 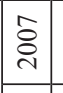 & $\stackrel{t}{\sigma}$ & in & $\stackrel{+}{m}$ & $\bar{i}$ & $\hat{\sigma}$ & $\stackrel{0}{\circ}$ & $\hat{m}$ & $\begin{array}{l}0 \\
i\end{array}$ & $\begin{array}{l}n \\
+ \\
+\end{array}$ & $\vec{i}$ & $\begin{array}{l}\infty \\
\text { in }\end{array}$ & $\overrightarrow{0}$ & $\stackrel{\infty}{i}$ & $\stackrel{\circ}{m}$ & $\stackrel{\infty}{0}$ & $\stackrel{\circ}{m}$ & $\stackrel{0}{8}$ \\
\hline & 范 & $\stackrel{2}{2}$ & $\begin{array}{l}n \\
\infty \\
\infty\end{array}$ & $\vec{n}$ & $\stackrel{6}{\circ}$ & $\stackrel{+}{i}$ & $\stackrel{\sim}{\sim}$ & $\stackrel{2}{\sim}$ & $\begin{array}{l}n \\
\cong\end{array}$ & $\stackrel{n}{n}$ & $\begin{array}{l}n \\
f \\
f\end{array}$ & $\stackrel{9}{=}$ & $\vec{n}$ & $\dot{\sigma}^{2}$ & $\vec{i}$ & $\stackrel{b}{i}$ & $\hat{\infty}$ & $\hat{m}$ & $\stackrel{8}{8}$ \\
\hline \multirow{6}{*}{ 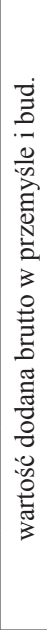 } & 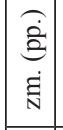 & 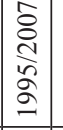 & $\stackrel{\infty}{\rightarrow}$ & $\begin{array}{l}0 \\
0 \\
1\end{array}$ & $\stackrel{+}{i}$ & $\because$ & 3 & $\overrightarrow{0}$ & $\stackrel{0}{\because}$ & m. & $\begin{array}{l}t \\
0 \\
c\end{array}$ & ช̂. & $\stackrel{t}{0}$ & $\overrightarrow{+\vec{t}}$ & ?. & $\overrightarrow{0}$ & $\stackrel{0}{-}$ & $\begin{array}{l}n \\
0 \\
0\end{array}$ & $\rtimes$ \\
\hline & \begin{tabular}{|l|}
0 \\
3 \\
3 \\
$\tilde{g}$
\end{tabular} & 客 & $\hat{0}$ & $\stackrel{\infty}{\underset{+}{+}}$ & $\tilde{m}$ & $\hat{i}$ & $\begin{array}{l}n \\
0\end{array}$ & $\stackrel{n}{n}$ & \begin{tabular}{|l}
$\infty$ \\
\pm \\
\pm
\end{tabular} & $\hat{i}$ & $\begin{array}{l}\circ \\
\stackrel{+}{*}\end{array}$ & $\underset{i}{i}$ & $\hat{n}$ & $\begin{array}{l}n \\
0 \\
0\end{array}$ & $\stackrel{\infty}{i}$ & $\hat{i}$ & $\stackrel{?}{\varrho}$ & $\stackrel{m}{m}$ & $\stackrel{0}{8}$ \\
\hline & $\begin{array}{l}\text { 吾 } \\
\text { 至 } \\
\end{array}$ & $\stackrel{2}{\sigma}$ & $\hat{\infty}$ & $\stackrel{\vec{r}}{n}$ & $\stackrel{0}{\circ}$ & $\vec{i}$ & ऊ̂ & $\stackrel{+}{\sim}$ & $\begin{array}{l}\infty \\
\rho^{-}\end{array}$ & $\begin{array}{c}0 \\
m\end{array}$ & $\begin{array}{l}\stackrel{+}{+} \\
\stackrel{+}{*}\end{array}$ & $\approx$ & $\underset{n}{\sim}$ & $\begin{array}{l}0 \\
\stackrel{\sim}{i}\end{array}$ & $\hat{n}$ & $\stackrel{b}{i}$ & $\hat{\infty}$ & $\stackrel{\infty}{n^{\infty}}$ & $\stackrel{0}{8}$ \\
\hline & 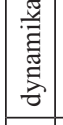 & $\begin{array}{l}8 \\
\vdots \\
1 \pi \\
2 \\
2 \\
-\end{array}$ & $\stackrel{\text { है }}{\stackrel{n}{n}}$ & $\underset{\sim}{\stackrel{\sim}{\sim}}$ & $\begin{array}{l}\sim \\
\stackrel{+}{N}\end{array}$ & $\mid \begin{array}{l}0 \\
0 \\
\infty \\
\infty \\
m\end{array}$ & 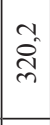 & $\stackrel{m}{=}$ & $\begin{array}{l}+ \\
\stackrel{2}{2} \\
\tilde{n}\end{array}$ & 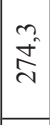 & 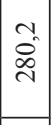 & $\begin{array}{l}\hat{\sigma} \\
\vec{m}\end{array}$ & $\begin{array}{l}0 \\
\infty \\
\infty \\
m\end{array}$ & $\begin{array}{l}3 \\
\text { bo } \\
\stackrel{1}{N}\end{array}$ & $\stackrel{n}{\tilde{m}}$ & $\frac{n}{n}$ & $\begin{array}{l}n \\
\hat{b} \\
n\end{array}$ & $\overrightarrow{\tilde{D}}$ & $\begin{array}{l}n \\
\hat{0} \\
\tilde{n}\end{array}$ \\
\hline & $\underset{N}{\mathbb{N}}$ & 客 & $\begin{array}{l}\overrightarrow{+} \\
m \\
m\end{array}$ & $\begin{array}{l}0 \\
m \\
i\end{array}$ & $\begin{array}{l}\stackrel{+}{0} \\
\stackrel{0}{0} \\
0 \\
=\end{array}$ & $\begin{array}{l}8 \\
0 \\
\infty \\
\infty\end{array}$ & 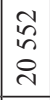 & $\begin{array}{l}\tilde{\infty} \\
\infty \\
\tilde{\lambda}\end{array}$ & \begin{tabular}{l}
$\hat{n}$ \\
$\hat{z}$ \\
$\gamma$ \\
\multirow{\gamma}{*}{}
\end{tabular} & $\begin{array}{l}q \\
+ \\
\infty\end{array}$ & 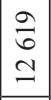 & 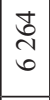 & $\begin{array}{l}\underset{\hat{\sim}}{2} \\
\infty \\
-\end{array}$ & $\begin{array}{l} \pm \\
\stackrel{m}{m} \\
\sim \\
\sim\end{array}$ & 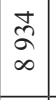 & $\begin{array}{l}\infty \\
\stackrel{\infty}{+} \\
\infty\end{array}$ & $\begin{array}{l}\text { 守 } \\
\text { d } \\
\text { ñ }\end{array}$ & $\begin{array}{l}\text { ¿̂ } \\
\text { O } \\
0\end{array}$ & $\frac{\substack{\infty \\
\stackrel{d}{I}}}{m}$ \\
\hline & $\overline{\bar{z}}$ & 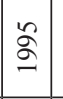 & స్ & $\begin{array}{l}\infty \\
\infty \\
i n\end{array}$ & 免 & $\frac{\infty}{\sim}$ & $\frac{\vec{f}}{0}$ & 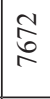 & 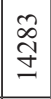 & $\begin{array}{l}0 \\
0 \\
0 \\
0\end{array}$ & \begin{tabular}{|l|} 
\\
0 \\
$y$ \\
\end{tabular} & $\stackrel{2}{I}$ & $\begin{array}{l}8 \\
0 \\
n \\
n\end{array}$ & $\begin{array}{c}\stackrel{n}{\Delta} \\
\stackrel{\sim}{\sim}\end{array}$ & $\vec{\delta}$ & $\hat{\text { Oे }}$ & ळ̂. & 尽 & 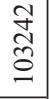 \\
\hline \multirow{6}{*}{ 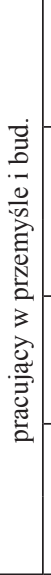 } & $\begin{array}{l}\text { } \\
\vec{\vdots} \\
\dot{\vec{n}}\end{array}$ & 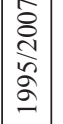 & $\overrightarrow{\hat{p}^{\prime}}$ & $\because$ & $\overrightarrow{0}$ & $\therefore$ & के & $\hat{i}$ & $\stackrel{t}{\rightarrow}$ & $\begin{array}{l}\infty \\
0 \\
0\end{array}$ & $\stackrel{ \pm}{0}$ & $\because$ & $\stackrel{0}{-1}$ & $\begin{array}{l}0 \\
\hat{i}\end{array}$ & $\begin{array}{l}n \\
0 \\
i\end{array}$ & $\stackrel{\infty}{0}$ & $\stackrel{+}{i}$ & ô & $\rtimes$ \\
\hline & \begin{tabular}{|l|}
0 \\
3 \\
3 \\
$\pi$
\end{tabular} & ڤ̊̀े & $\tilde{\infty}^{n}$ & 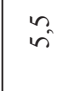 & $\stackrel{6}{\circ}$ & $\hat{i}$ & $\stackrel{+}{\sim}$ & $\stackrel{0}{\sim}$ & $\begin{array}{l}0 \\
i\end{array}$ & $\begin{array}{l}n \\
i\end{array}$ & $\vec{n}$ & $\vec{i}$ & $\begin{array}{l}\infty \\
i n\end{array}$ & $\begin{array}{l}0 \\
\therefore\end{array}$ & $\left|\begin{array}{l}\infty \\
i\end{array}\right|$ & $\stackrel{m}{m}$ & $\stackrel{1}{=}$ & $\stackrel{\infty}{m}$ & $\begin{array}{l}0 \\
\stackrel{8}{8}\end{array}$ \\
\hline & 喜 & \begin{tabular}{|l} 
\\
$\curvearrowright$
\end{tabular} & $m_{\infty}^{m}$ & $\stackrel{f}{\vec{f}}$ & $\hat{m}$ & $\bar{i}$ & $\begin{array}{c}m \\
\infty^{2}\end{array}$ & $\begin{array}{l}m \\
\infty\end{array}$ & $\stackrel{m}{=}$ & \begin{tabular}{|c|}
$\dot{m}_{0}$ \\
\end{tabular} & $\tilde{F}^{-}$ & $\vec{i}$ & $\begin{array}{l}\infty \\
+ \\
\forall\end{array}$ & $\begin{array}{l}\tilde{2} \\
\tilde{a}^{\prime}\end{array}$ & $\dot{m}_{m}$ & $\hat{n}$ & \begin{tabular}{|c|}
$\infty$ \\
$\infty$
\end{tabular} & 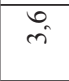 & $\begin{array}{l}0 \\
\stackrel{0}{0}\end{array}$ \\
\hline & 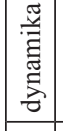 & $\begin{array}{l}8 \\
\frac{0}{11} \\
2 \\
2\end{array}$ & $\overrightarrow{\vec{\infty}}$ & $\stackrel{+}{a}$ & مू & $\begin{array}{l}0 \\
8 \\
\infty\end{array}$ & $\vec{m}$ & $\begin{array}{l}\infty \\
\mathbb{t}^{\prime}\end{array}$ & $\begin{array}{l}0 \\
-\pi\end{array}$ & $\frac{m}{6}$ & $\mid \begin{array}{c}0 \\
\infty \\
\infty\end{array}$ & $\begin{array}{c}r \\
\tilde{d} \\
\infty\end{array}$ & $\hat{\infty}$ & $\begin{array}{l}0 \\
\dot{8} \\
8\end{array}$ & $\begin{array}{l}+ \\
\stackrel{\sigma}{0}\end{array}$ & $\begin{array}{l}0 \\
\stackrel{0}{0}\end{array}$ & \begin{tabular}{l}
$n$ \\
\multirow{0}{0}{}
\end{tabular} & $\vec{\infty}$ & $\underset{\infty}{\infty}$ \\
\hline & $\begin{array}{l}0 \\
0.0 \\
0 \\
0\end{array}$ & 离 & $\vec{\pi}$ & $\stackrel{m}{\sim}$ & $\exists$ & $\stackrel{t}{0}$ & $\begin{array}{l}\infty \\
\infty \\
\sim\end{array}$ & $\hat{\grave{\lambda}}$ & $\tilde{\sigma}$ & $\stackrel{\infty}{\infty}$ & $\stackrel{\infty}{2}$ & $\infty$ & 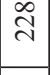 & $\frac{0}{6}$ & $\exists$ & సे & \begin{tabular}{|l}
$\infty$ \\
$\stackrel{\infty}{f}$
\end{tabular} & 守 & ষ্ণ \\
\hline & $\dot{\infty}$ & ڤ̆ & ஓి & 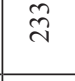 & $\stackrel{\infty}{\cong}$ & సे & సે & ફे & $\hat{n}$ & $\stackrel{8}{\circ}$ & $\stackrel{a}{a}$ & 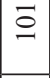 & $\overrightarrow{\vec{n}}$ & $\frac{\sigma}{\sigma}$ & $\stackrel{8}{-1}$ & $\vec{\beth}$ & $\frac{\partial}{\gamma}$ & $\Xi$ & $\begin{array}{l}\infty \\
\stackrel{0}{f}\end{array}$ \\
\hline & $\begin{array}{l}0 \\
\frac{1}{N} \\
0 \\
0 \\
0 \\
0 \\
0 \\
3\end{array}$ & & 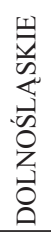 & $\begin{array}{ll}1 & 1 \\
0 & 0 \\
0 & 0 \\
0 & 0 \\
3 & 0 \\
3 & 0 \\
3 & 0\end{array}$ & 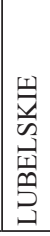 & 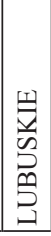 & 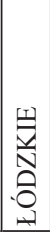 & 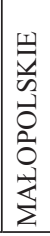 & 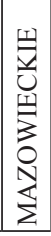 & \begin{tabular}{|l|}
01 \\
0 \\
0 \\
0 \\
0 \\
0 \\
0 \\
0 \\
\end{tabular} & 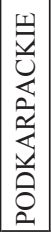 & 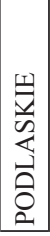 & \begin{tabular}{|l}
1 \\
0 \\
0 \\
0 \\
0 \\
0 \\
2 \\
0 \\
0 \\
\end{tabular} & 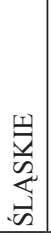 & 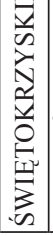 & 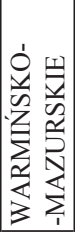 & 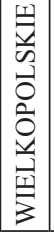 & 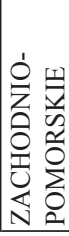 & 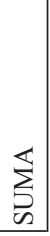 \\
\hline
\end{tabular}


przełomie XX i XXI w. krajów, takich jak Irlandia i Hiszpania, nadal wzmacniają potencjał tego sektora mierzony wartością dodaną brutto, co nie pozwala na aprobatę stawianej w licznych opracowaniach hipotezy o powszechnych procesach dezindustrializacji Europy. Przemiany potencjału przemysłowego są więc raczej potwierdzeniem procesów reindustrializacji, w których przemysł pracochłonny ustępuje miejsca przemysłom wiedzochłonnym, cechującym się wyższą wartością dodaną, która niweluje zmniejszającą się rolę przemysłu w bezpośrednim aktywizowaniu zasobów pracy. Jest to coraz wyraźniej zarysowująca się cecha przemysłu krajów przechodzących z fazy postindustrialnej do gospodarki opartej na wiedzy.

\section{STRUKTURA PRZESTRZENNA PRZEMYSŁU Polski}

Analiza udziału województw w strukturze pracujących w przemyśle i budownictwie wskazuje na duży udział tradycyjnie wysokouprzemysłowionych województw śląskiego, mazowieckiego i wielkopolskiego, przy czym należy zauważyć, że województwo śląskie znacznie zmniejszyło swój udział w krajowym potencjale pracujących w przemyśle z 19,2\% do 15,6\%, tj. o -3,6 p.p., natomiast woj. wielkopolskie i mazowieckie znacząco zwiększyły swój udział. W świetle udziału w wartości dodanej brutto wśród trzech województw, w których wskaźnik ten jest najwyższy, oprócz śląskiego i mazowieckiego znajduje się województwo dolnośląskie. Jest to konsekwencja nowych lokalizacji i intensywnego rozwoju w ostatnich latach przedsiębiorstw średniej i wysokiej techniki na terenie województwa dolnośląskiego (Raczyk, Dobrowolska-Kaniewska 2009)1, które cechują się mniejszą pracochłonnością, ale większą wartością dodaną. Jednak w świetle obliczonego miernika syntetycznego (w oparciu o dwa mierniki empiryczne: liczbę pracujących i wartość dodaną brutto) na trzecim miejscu w Polsce pod względem udziału w potencjale przemysłowym znajduje się woj. wielkopolskie.

Analiza ilorazów lokalizacji dla miernika syntetycznego wskazuje, że największa koncentracja działalności przemysłowej występuje w województwach Polski południowo-zachodniej i centralnej (tab. 2, ryc. 5 a,b). W badanym okresie stwierdzono największe spadki wartości ilorazu w województwie śląskim (z 5,1 do 4,1) i opolskim (z 1,1 do 0,9), największy wzrost zanotowano w województwie wielkopolskim (z 0,9 do 1,1).

Obliczone współczynniki lokalizacji (koncentracji Florence’a) wskazują na niewielkie zmniejszenie się w badanym okresie niskiego stopnia koncentracji przemysłu wg województw, przy czym w przypadku wartości dodanej brutto wskaźniki te są wyższe niż w przypadku liczby pracujących. Świadczy to o wyższym stopniu koncentracji bardziej zaawansowanych technologicznie przemysłów o wysokiej wartości dodanej.

\footnotetext{
${ }^{1}$ Warto jednak zwrócić w tym miejscu uwagę, za A. Świdurską (2009), że rozwój przemysłu wysokiej techniki w Polsce nie przebiegał w ostatnich latach w sposób ciaggły, a Polska nadal charakteryzuje się niskim udziałem produktów wysokiej techniki w ogólnej wartości sprzedaży.
} 


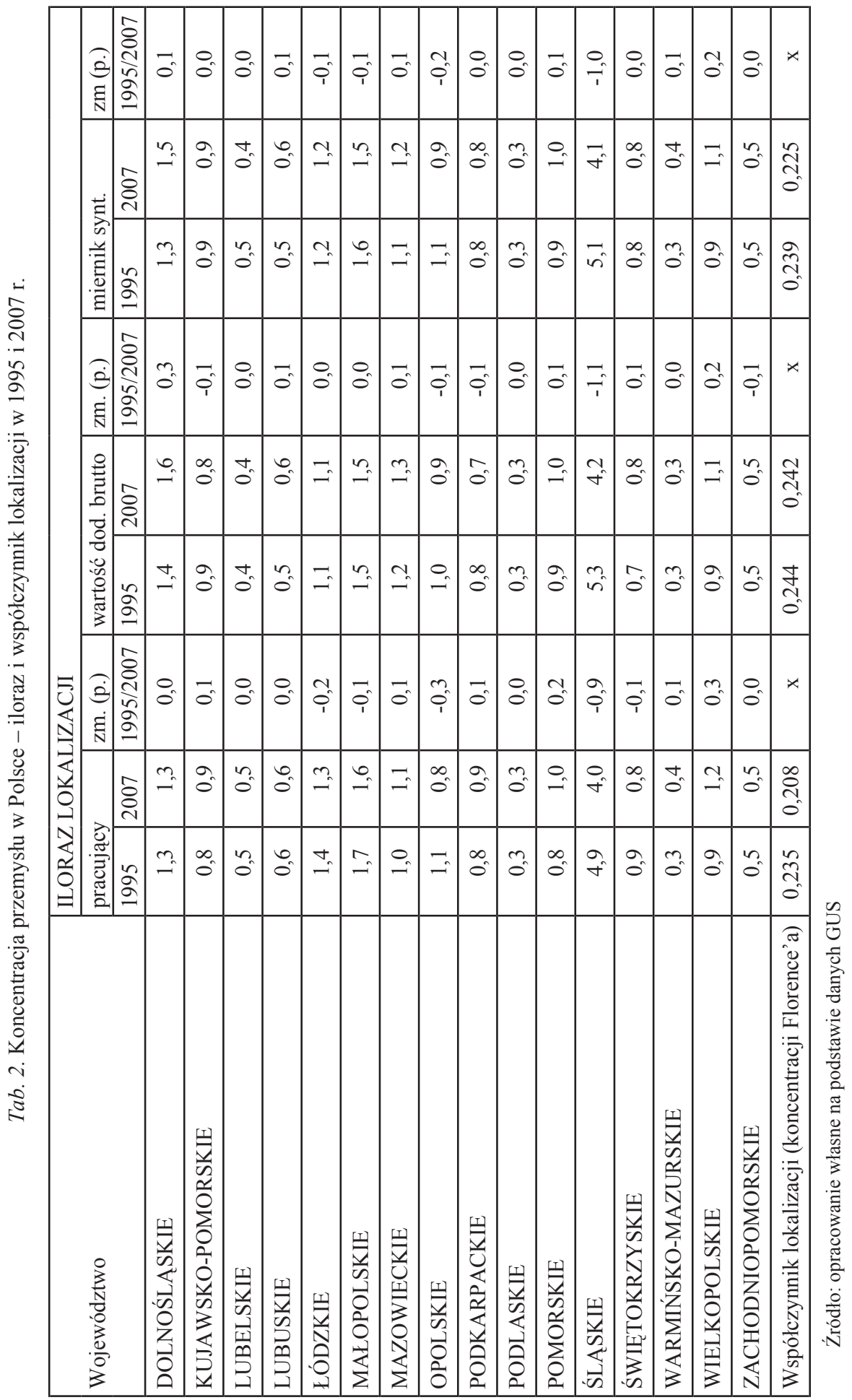


A

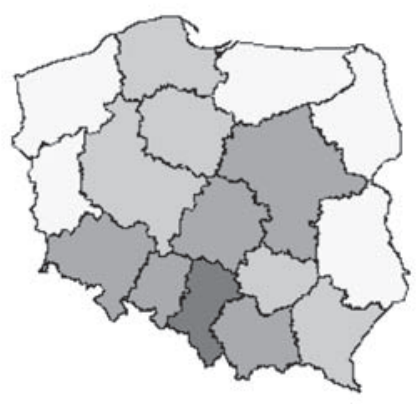

B

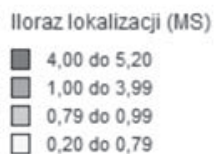

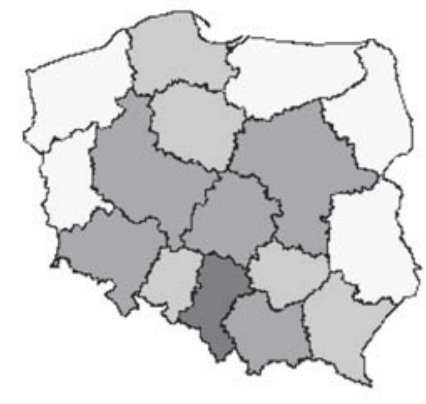

Ryc. 5. Iloraz lokalizacji przemysłu (dla miernika syntetycznego) w 1995 (A) i 2007 (B) r.

Źródło: opracowanie własne na podstawie danych GUS

\section{WYdAJNOŚĆ PRACY W PRZEMYŚLE POLSKI}

Analiza wydajności pracy obliczonej jako wartość dodana brutto na 1 pracującego w przemyśle wskazuje, że najbardziej konkurencyjnymi pod tym względem województwami są mazowieckie, opolskie i dolnośląskie (ryc. 6). Stosunkowo wysokimi wskaźnikami wydajności pracy charakteryzują się województwa śląskie, małopolskie, świętokrzyskie i lubuskie, w których zanotowano również bardzo wysokie indeksy dynamiki tego wskaźnika.

Jak wskazano we wcześniejszej analizie (Rachwał, Wiedermann, Kilar 2008a), jest to konsekwencja napływu nowych inwestycji przemysłowych, które wskazują na ciążenie ich w kierunku najbardziej rozwiniętych ośrodków przemysłowych Polski południowo-zachodniej i centralnej. Znacznie mniejsza konkurencyjność zasobów pracy w tym zakresie w województwach Polski północnej i wschodniej powoduje, że inwestorzy, znajdując lepsze warunki do lokalizacji przedsięwzięć w zachodnich województwach, będą prawdopodobnie dalej omijali te województwa. Dzieje się tak pomimo stosunkowo dobrych w województwach wschodniej i północnej Polski wskaźników jakości zasobów kapitału ludzkiego i innowacyjności tych regionów (Borowiec, Dorocki, Jenner 2009). Wcześniejsze badania nad zróżnicowaniem wydajności kosztów i wydajności pracy w regionach UE (Rachwał, Wiedermann, Kilar 2008a) wskazują jednak, że polskie regiony cechują się niską konkurencyjnością w tym zakresie w porównaniu z regionami krajów zachodnioeuropejskich. 


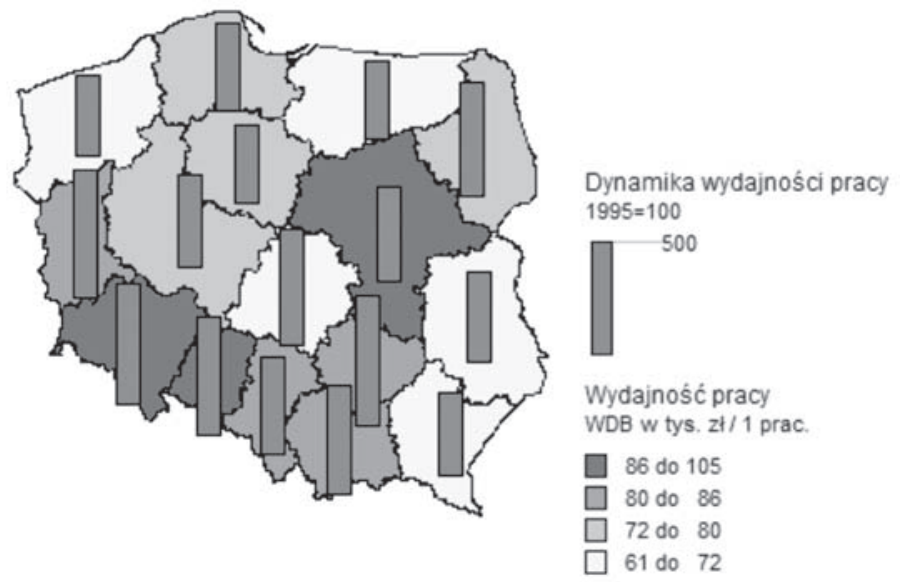

Ryc. 6. Wydajność pracy w 2007 r. i dynamika zmian wydajności w latach 1995-2007

Źródło: opracowanie własne na podstawie danych GUS

\section{STRUKTURA DZIAŁOWA PRZEMYSŁU POLSKI}

Analizując dane dotyczące zmiany struktur zatrudnienia w przemyśle wg sekcji i działów, należy zauważyć, że wielkość zatrudnienia w badanym okresie spadała z blisko 3,7 do 3,1 mln pracujących (tab. 3), natomiast wartość produkcji sprzedanej (w cenach bieżących) wzrosła blisko czterokrotnie. Analiza zróżnicowania struktur zatrudnienia i wartości produkcji sprzedanej w przemyśle wg sekcji, ze względu na obowiązującą klasyfikację, w której blisko 90\% udział ma sekcja C (przetwórstwo przemysłowe), nie pozwala jednak na wyciągnięcie wniosków dotyczących przemian struktury branżowej polskiego przemysłu. W celu uchwycenia zmian strukturalnych w przemyśle konieczna jest więc analiza na poziomie działów.

Najwięcej pracujących i wartości produkcji sprzedanej skupiają działy produkcji artykułów spożywczych i napojów, produkcji maszyn i urządzeń, w ostatnich latach także produkcja wyrobów z metali. Stosunkowo dużą rolę odgrywa górnictwo (w analizie ujęte jako wszystkie 4 działy sekcji C Górnictwo, gdyż ponad 90\% potencjału zatrudnienia grupuje górnictwo węgla). Działy nowoczesne produkcji (DL 30 do DL33) charakteryzują się stosunkowo niskim potencjałem zatrudnienia i wartości produkcji sprzedanej.

Analiza dynamiki zmian zatrudnienia w przemyśle wg działów wskazuje na prawie dwukrotny wzrost zatrudnienia w dziale produkcja maszyn biurowych i komputerów oraz przetwarzanie odpadów, ale trzeba mieć świadomość znikomego znaczenia tych działów w potencjale zatrudnienia (wzrost ten „łatwo” było osiągnąć, gdyż zatrudnienie w roku bazowym było bardzo niskie - otwarcie jednej większej fabryki przy zatrudnieniu ok. 4-5 tys. znacząco wpływa na wzrost wskaźnika). Największy spadek zatrudnienia i wartości produkcji sprzedanej (nawet do 50\%) zanotowano w działach przemysłu tradycyjnego, np. górnictwie, włókiennictwie, produkcji odzieży, skór i wyrobów skórzanych. Jest to oczywista 
konsekwencja zmniejszającej się roli węgla kamiennego i brunatnego w gospodarce oraz systematycznego tracenia od połowy lat. 90 pozycji kraju o niskich kosztach produkcji, co w przypadku produkcji włókienniczej i odzieży ma decydujące znaczenie.

Zmiany wielkości zatrudnienia i wartości produkcji sprzedanej w poszczególnych działach znalazły swoje odzwierciedlenie w zmianach struktury działowej, w której można zaobserwować nadal utrzymujący się wysoki udział przemysłu spożywczego oraz maszyn i urządzeń, ale widoczny jest znaczący spadek znaczenia górnictwa, które straciło II pozycję w rankingu z 1995 r. (zarówno pod względem liczby pracujących jak wartości produkcji sprzedanej) na rzecz innych działów (produkcji wyrobów z metali w przypadku pracujących i pojazdów samochodowych w przypadku wartości produkcji sprzedanej).

W celu syntetycznego określenia stopnia zróżnicowania działowego przemysłu obliczono wskaźnik Rodgersa, zmodyfikowany i wyrównany przez Warakomską (Troc 1991). Niewielkie zmiany wskaźnika zróżnicowania działowego przemysłu w Polsce wskazują na utrzymanie średniego zróżnicowania działalności przemysłowej, niewielki spadek wartości wskaźnika może świadczyć o upodobnianiu się struktury zatrudnienia do krajów wysokorozwiniętych.

Analiza zmian udziału poszczególnych działów w strukturze zatrudnienia i produkcji sprzedanej przemysłu wskazuje, że tracą na znaczeniu najbardziej tradycyjne, pracochłonne przemysły, takie jak górnictwo, produkcja odzieży, włókiennictwo, produkcja skór, ale także produkcja maszyn i urządzeń, energetyka i przemysł chemiczny. Znacząco zwiększyły swój udział w strukturze takie działy, jak produkcja wyrobów z metali, wyrobów gumowych i z tworzyw sztucznych, produkcja mebli i pojazdów samochodowych. Działy te trudno zaliczyć do najbardziej zaawansowanych technologicznie. Jak się wydaje, można mówić o zaznaczeniu się tu dużych inwestycji kapitału zagranicznego w te działy produkcji.

Na koniec rodzi się pytanie, jak struktura ta wygląda na tle innych krajów europejskich. Struktura działowa przemysłu w poszczególnych krajach UE (dla których były dostępne dane) jest bardzo zróżnicowana. W większości z nich zauważalny jest duży udział przemysłu spożywczego i tytoniowego (złączone razem ze względu na tajemnicę statystyczna), produkcji maszyn i urządzeń oraz wyrobów z metali. Udział działów przemysłu najbardziej zaawansowanych technologicznie (DL30-DL33) jest stosunkowo niewielki, ale trzeba mieć na uwadze, że są to przemysły mało pracochłonne, ale cechujące się dużą wartością dodaną.

Obliczony wskaźnik zróżnicowania działowego Rodgersa wskazuje, że przemysł Polski jest dużo bardziej zróżnicowany niż w innych krajach europejskich. Przemysł Litwy, Danii, Łotwy czy Niemiec jest mniej zróżnicowany, choć należy podkreślić, że wskaźniki te różnią się nieznacznie od siebie.

Przeprowadzone próby analizy podobieństwa struktur działowych przemysłu (w oparciu o miernik syntetyczny obejmujący dwa mierniki empiryczne - pracujących i wartość dodaną brutto) w poszczególnych krajach UE pozwalają na wyróżnienie w 1995 r. 5 grup państw o podobnych strukturach działowych (ryc. 7 a). Polska znalazła się w grupie 4 z innymi krajami Europy Środkowej i Wschodniej (Bułgarią, Rumunią, Czechami i Słowacją). 
Tab. 3. Pracujący i produkcja sprzedana w przemyśle i budownictwie

\begin{tabular}{|c|c|c|c|c|c|c|}
\hline \multirow{3}{*}{ Działy przemysłu } & \multicolumn{6}{|c|}{ Pracujący } \\
\hline & \multicolumn{2}{|c|}{ tys. osób } & \multirow{2}{*}{\begin{tabular}{|l|} 
dynamika \\
$1995=100$
\end{tabular}} & \multicolumn{2}{|c|}{$\begin{array}{c}\text { struktura } \\
\mathrm{W} \% \\
\end{array}$} & \multirow{2}{*}{$\frac{\text { zm. (pp.) }}{1995 / 2007}$} \\
\hline & 1995 & 2007 & & 1995 & 2007 & \\
\hline C10-14 Górnictwo & 357,1 & 180,3 & 50,5 & 9,6 & 5,7 & $-3,8$ \\
\hline DA15 Prod. art. spoż. i napojów & 529,7 & 466,2 & 88,0 & 14,2 & 14,8 & 0,6 \\
\hline DA16 Prod. wyr. tytoniowych & 12,9 & 7,3 & 56,6 & 0,3 & 0,2 & $-0,1$ \\
\hline DA17 Włókiennictwo & 168,1 & 85,8 & 51,0 & 4,5 & 2,7 & $-1,8$ \\
\hline DB18 Prod. odzieży i wyr. futrzarskich & 319,9 & 162,3 & 50,7 & 8,6 & 5,2 & $-3,4$ \\
\hline DC19 Prod. skór i wyrobów ze skór & 90,2 & 37,2 & 41,2 & 2,4 & 1,2 & $-1,2$ \\
\hline DD20 Prod. drewna i wyr. z drewna & 133,5 & 150,8 & 113,0 & 3,6 & 4,8 & 1,2 \\
\hline DE21 Prod. masy włóknistej oraz papieru & 41,5 & 45,6 & 109,9 & 1,1 & 1,5 & 0,3 \\
\hline DE22 Dział. wydawnicza; poligrafia & 82,5 & 105,2 & 127,5 & 2,2 & 3,3 & 1,1 \\
\hline DF23 Prod. koksu i prod. rafinacji ropy naft. & 27,6 & 15,2 & 55,1 & 0,7 & 0,5 & $-0,3$ \\
\hline DG24 Prod. wyr. chemicznych & 141,1 & 107,2 & 76,0 & 3,8 & 3,4 & $-0,4$ \\
\hline $\begin{array}{l}\text { DH25 Prod. wyr. gumowych i z tw. sztucz- } \\
\text { nych }\end{array}$ & 105,5 & 172,0 & 163,0 & 2,8 & 5,5 & 2,6 \\
\hline DI26 Prod. wyr. z pozost. sur. niemetal. & 182,0 & 152,2 & 83,6 & 4,9 & 4,8 & 0,0 \\
\hline DJ27 Prod. metali & 164,1 & 72,1 & 43,9 & 4,4 & 2,3 & $-2,1$ \\
\hline DJ28 Prod. wyr. z metali & 192,1 & 291,7 & 151,8 & 5,2 & 9,3 & 4,1 \\
\hline DK29 Prod. maszyn i urządzeń & 299,7 & 217,6 & 72,6 & 8,0 & 6,9 & $-1,1$ \\
\hline DL30 Prod. maszyn biurowych i komput. & 4,7 & 8,8 & 187,2 & 0,1 & 0,3 & 0,2 \\
\hline DL31 Prod. maszyn i aparat. elektrycz. & 99,7 & 115,1 & 115,4 & 2,7 & 3,7 & 1,0 \\
\hline DL32 Prod. sprzętu radio-TV i telekomun. & 51,1 & 41,9 & 82,0 & 1,4 & 1,3 & 0,0 \\
\hline DL33 Prod. instrum. med., precyzyjnych & 49,4 & 50,8 & 102,8 & 1,3 & 1,6 & 0,3 \\
\hline $\begin{array}{l}\text { DM34 Prod. pojazdów samoch., przyczep } \\
\text { i naczep }\end{array}$ & 102,6 & 136,2 & 132,7 & 2,8 & 4,3 & 1,6 \\
\hline DM35 Prod. pozostałego sprzętu transport. & 112,5 & 74,1 & 65,9 & 3,0 & 2,4 & $-0,7$ \\
\hline $\begin{array}{l}\text { DN36 Prod. mebli, pozostała dział. pro- } \\
\text { dukcyjna }\end{array}$ & 185,0 & 219,1 & 118,4 & 5,0 & 7,0 & 2,0 \\
\hline DN37 Przetwarzanie odpadów & 7,1 & 13,0 & 183,1 & 0,2 & 0,4 & 0,2 \\
\hline $\begin{array}{l}\text { E40 Wytw. i zaopatr. w en. el., gaz, } \\
\text { parę w. i g. wodę }\end{array}$ & 213,7 & 156,3 & 73,1 & 5,7 & 5,0 & $-0,8$ \\
\hline E41 Pobór, uzdatnianie i rozprow. wody & 55,5 & 58,9 & 106,1 & 1,5 & 1,9 & 0,4 \\
\hline PRZEMYSŁ ogółem & 3728,8 & 3142,9 & 84,3 & 100,0 & 100,0 & $\mathrm{x}$ \\
\hline
\end{tabular}


w Polsce wg działów PKD w 1995 i 2007 r.

\begin{tabular}{|c|c|c|c|c|c|c|c|c|c|}
\hline \multicolumn{6}{|c|}{ Produkcja sprzedana } & \multicolumn{4}{|c|}{ Miernik syntetyczny } \\
\hline \multicolumn{2}{|c|}{ mln złotych } & \multirow{2}{*}{$\begin{array}{l}\text { dynamika } \\
1995=100\end{array}$} & \multicolumn{2}{|c|}{$\begin{array}{c}\text { struktura } \\
\text { w } \%\end{array}$} & \multirow{2}{*}{$\begin{array}{c}\text { zm. (pp.) } \\
1995 / 2007\end{array}$} & \multicolumn{2}{|c|}{ wartość } & \multirow{2}{*}{$\begin{array}{l}\text { dynamika } \\
1995=100\end{array}$} & \multirow{2}{*}{$\frac{\text { zm. (pp.) }}{1995 / 2007}$} \\
\hline 1995 & 2007 & & 1995 & 2007 & & 1995 & 2007 & & \\
\hline 19535,6 & 39846,8 & 204,0 & 8,0 & 4,5 & $-3,5$ & 8,8 & 5,1 & 58,3 & $-3,7$ \\
\hline 46658,4 & 141789,9 & 303,9 & 19,1 & 16,0 & $-3,1$ & 16,6 & 15,4 & 92,7 & $-1,2$ \\
\hline 1816,3 & 4215,7 & 232,1 & 0,7 & 0,5 & $-0,3$ & 0,5 & 0,4 & 65,1 & $-0,2$ \\
\hline 6399,0 & 11241,5 & 175,7 & 2,6 & 1,3 & $-1,3$ & 3,6 & 2,0 & 56,1 & $-1,6$ \\
\hline 6329,5 & 8508,5 & 134,4 & 2,6 & 1,0 & $-1,6$ & 5,6 & 3,1 & 54,8 & $-2,5$ \\
\hline 2679,3 & 3852,5 & 143,8 & 1,1 & 0,4 & $-0,7$ & 1,8 & 0,8 & 46,1 & $-0,9$ \\
\hline 6813,0 & 26309,0 & 386,2 & 2,8 & 3,0 & 0,2 & 3,2 & 3,9 & 122,0 & 0,7 \\
\hline 5402,8 & 17274,2 & 319,7 & 2,2 & 2,0 & $-0,3$ & 1,7 & 1,7 & 102,4 & 0,0 \\
\hline 6473,2 & 24789,6 & 383,0 & 2,6 & 2,8 & 0,2 & 2,4 & 3,1 & 126,5 & 0,6 \\
\hline 10137,4 & 43645,9 & 430,5 & 4,1 & 4,9 & 0,8 & 2,4 & 2,7 & 110,8 & 0,3 \\
\hline 16692,0 & 49318,1 & 295,5 & 6,8 & 5,6 & $-1,3$ & 5,3 & 4,5 & 84,6 & $-0,8$ \\
\hline 7770,0 & 44697,7 & 575,3 & 3,2 & 5,1 & 1,9 & 3,0 & 5,3 & 175,2 & 2,3 \\
\hline 9089,8 & 41965,3 & 461,7 & 3,7 & 4,7 & 1,0 & 4,3 & 4,8 & 111,5 & 0,5 \\
\hline 16057,1 & 42672,8 & 265,8 & 6,6 & 4,8 & $-1,7$ & 5,5 & 3,6 & 64,9 & $-1,9$ \\
\hline 9367,3 & 60116,2 & 641,8 & 3,8 & 6,8 & 3,0 & 4,5 & 8,0 & 178,9 & 3,5 \\
\hline 13689,3 & 49921,3 & 364,7 & 5,6 & 5,6 & 0,0 & 6,8 & 6,3 & 92,1 & $-0,5$ \\
\hline 478,6 & 2126,7 & 444,4 & 0,2 & 0,2 & 0,0 & 0,2 & 0,3 & 161,7 & 0,1 \\
\hline 6179,4 & 30366,2 & 491,4 & 2,5 & 3,4 & 0,9 & 2,6 & 3,5 & 136,4 & 0,9 \\
\hline 3346,8 & 18645,8 & 557,1 & 1,4 & 2,1 & 0,7 & 1,4 & 1,7 & 125,6 & 0,4 \\
\hline 2197,2 & 8931,0 & 406,5 & 0,9 & 1,0 & 0,1 & 1,1 & 1,3 & 118,1 & 0,2 \\
\hline 8704,3 & 79584,9 & 914,3 & 3,6 & 9,0 & 5,4 & 3,2 & 6,7 & 211,1 & 3,5 \\
\hline 5678,8 & 13985,1 & 246,3 & 2,3 & 1,6 & $-0,7$ & 2,7 & 2,0 & 73,7 & $-0,7$ \\
\hline 7608,6 & 32539,8 & 427,7 & 3,1 & 3,7 & 0,6 & 4,0 & 5,3 & 131,9 & 1,3 \\
\hline 779,9 & 4321,7 & 554,1 & 0,3 & 0,5 & 0,2 & 0,3 & 0,5 & 177,0 & 0,2 \\
\hline 22441,0 & 77154,7 & 343,8 & 9,2 & 8,7 & $-0,5$ & 7,5 & 6,8 & 91,8 & $-0,6$ \\
\hline 2108,1 & 7154,3 & 339,4 & 0,9 & 0,8 & $-0,1$ & 1,2 & 1,3 & 114,1 & $-0,2$ \\
\hline 244432,7 & 884975,2 & 362,1 & 100,0 & 100,0 & $\mathrm{x}$ & 100,0 & 100,0 & $\mathrm{x}$ & $\mathrm{x}$ \\
\hline
\end{tabular}


A.

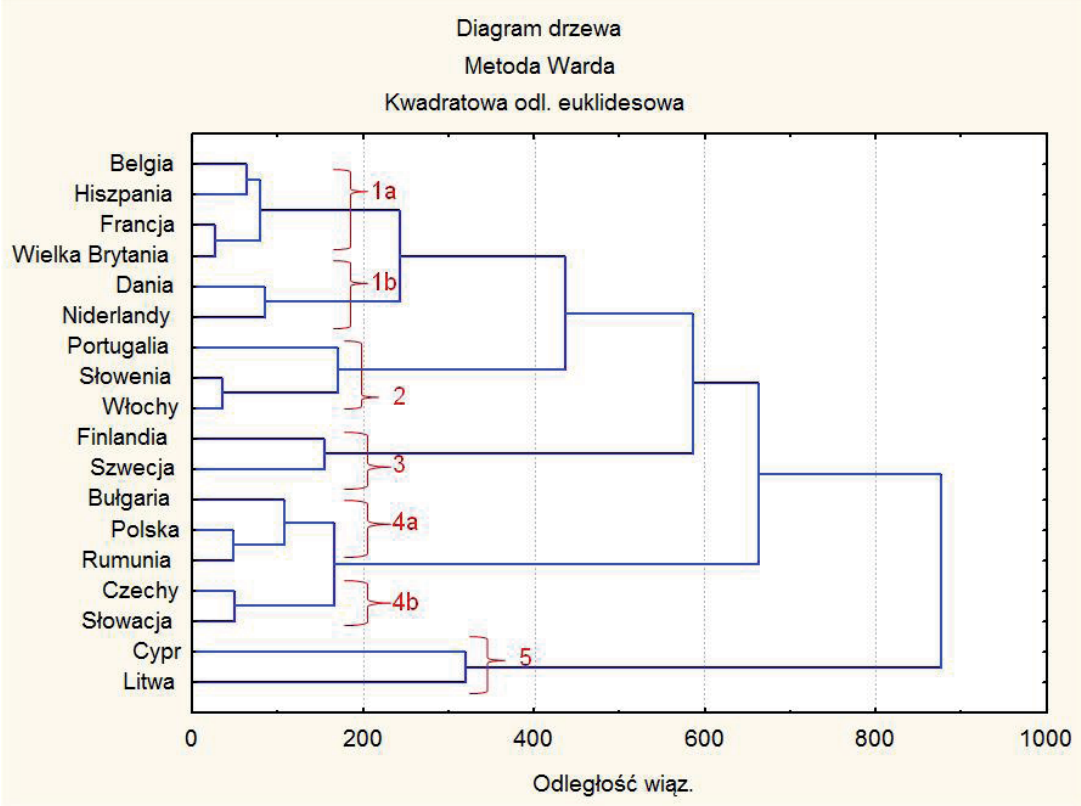

B.

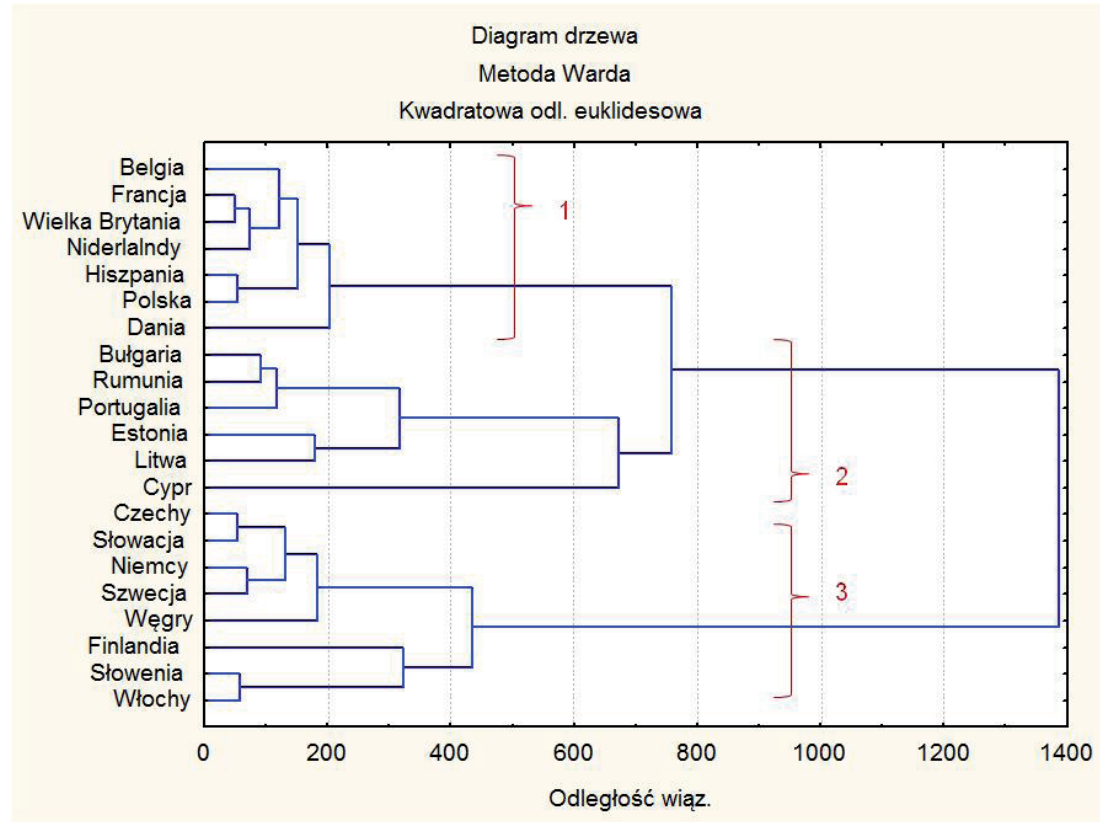

Ryc. 7. Podobieństwo struktur działowych przemysłu wybranych krajów UE w świetle analizy skupień (wg miernika synt.) w 1995 i 2007 r.

Źródło: opracowanie własne na podstawie danych Eurostat 
Przemiany struktury przemysłu w Polsce doprowadziły jednak w 2007 r. do sytuacji, w której wśród 3 wyróżnionych grup państw (ryc. 7b) Polska znalazła się w grupie 1, razem z Belgią, Francją, Wielką Brytania, Niderlandami, Hiszpanią i Danią, a nie - jak mogło by się wydawać - z pozostałymi krajami Europy Środkowej i Wschodniej.

Z punktu widzenia analizy konkurencyjności polskiego przemysłu na rynkach światowych (w tym jednolitym rynku europejskim) w warunkach kształtowania się społeczeństwa informacyjnego i budowy gospodarki opartej na wiedzy istotne wydaje się pytanie o udział najbardziej zaawansowanych technologicznie działów przemysłu w strukturze zatrudnienia. Przemysły te generują szereg efektów mnożnikowych w rozwoju społeczno-gospodarczym i cechują się o wiele korzystniejszymi efektami ekonomicznymi działalności w porównaniu z przemysłem tradycyjnym. Analiza wskazuje jednak na niski potencjał zatrudnienia i wartości dodanej brutto tych przemysłów w Polsce na tle innych krajów (ryc. 8).

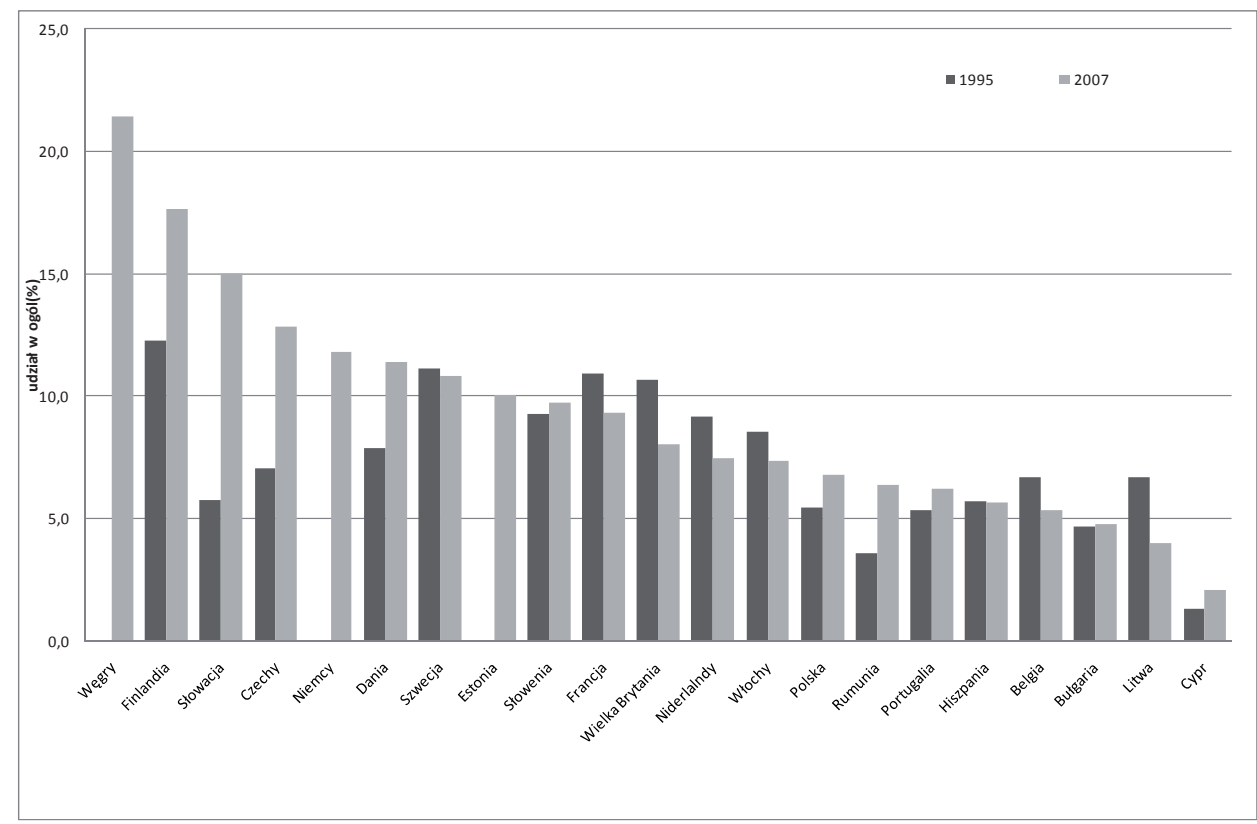

* Do działów zaawansowanych technologicznie zaliczono: DL30 Prod. maszyn biurowych i komputerów; DL31 Prod. maszyn i aparat. elektrycz.; DL32 Prod. sprzętu i urz. radiowych, TV i telekomun.; DL33 Prod. instrum. med., precyzyjnych i optycznych, zegarów

Ryc. 8. Udział zawansowanych technologicznie* działów przemysłu w strukturze miernika syntetycznego dla wybranych krajów UE w 1995 i 2007 r.

Źródło: opracowanie własne na podstawie danych Eurostat

Udział ten jest znacząco poniżej średniej europejskiej i jest dużo niższy niż np. w przypadku Węgier czy Czech, choć zauważalna jest tendencja wzrostowa. Ma to swoje korzenie w niskim potencjale badawczo-rozwojowym polskiej gospodarki. Na tle pozostałych krajów Unii Europejskiej potencjał zatrudnienia w B $+\mathrm{R}$ w Polsce i jego udział w ogóle pracujących nie jest znaczący, na co wskazują liczne badania (m.in. Borowiec, Dorocki, Jenner 2009; Gierańczyk 2009; Rachwał, Wiedermann, Kilar 2009). 


\section{WNIOSKI}

Przedstawiona analiza przemian struktury przestrzennej i działowej przemysłu Polski na tle innych krajów UE i zmiany roli tego sektora w gospodarce kraju pozwala na wyciągnięcie następujących wniosków:

- Udział przemysłu w strukturze pracujących oraz wartości dodanej brutto wykazuje w Polsce tendencję malejąca, podobnie jak w większości analizowanych krajów UE, należy jednak podkreślić niewielki jego wzrost w latach 2002-2007.

- Niewielki spadek udziału przemysłu w latach 1995-2007 spowodował, że Polska nadal należy do grupy krajów UE o wysokim udziale przemysłu w gospodarce.

- Udział przemysłu w wartości dodanej brutto jest o kilka punktów procentowych wyższy niż udział przemysłu w strukturze pracujących, co świadczy o coraz mniejszym znaczeniu przemysłu w aktywizacji zasobów pracy.

- Analiza przemian struktury przestrzennej przemysłu Polski wskazuje na nadal duży udział przemysłu w gospodarce poszczególnych regionów; stwierdzono wysokie ilorazy lokalizacji w tradycyjnie wysokouprzemysłowionych województwach Polski południowo-zachodniej i centralnej.

- Zauważalny jest proces dekoncentracji przemysłu, szczególnie w województwie śląskim, przesunięcia tego potencjału następują jednak nie w kierunku województw peryferyjnych, o mniejszym znaczeniu przemysłu w gospodarce, ale do województw o tradycyjnie silnym potencjale przemysłowym, takich jak woj. dolnośląskie czy wielkopolskie.

- W strukturze zatrudnienia oraz wartości dodanej brutto tracą na znaczeniu działy tradycyjne przemysłu, jak górnictwo, włókiennictwo, produkcja metali czy odzieży, co ma związek z relokacją tego typu działalności do krajów o niższych kosztach pracy; tendencję tę, z punktu widzenia budowy gospodarki opartej na wiedzy, należy ocenić korzystnie.

- Najbardziej konkurencyjnymi pod względem wydajności pracy województwami są regiony Polski południowo-zachodniej i centralnej; województwa o niskiej wydajności (podkarpackie, lubelskie, zachodniopomorskie, warmińsko-mazurskie) charakteryzują się również niską dynamiką wzrostu wydajności.

- Przemiany struktury przestrzennej przemysłu wskazują na pogłębianie się różnic międzyregionalnych w zakresie rozwoju przemysłu, a nie ich zmniejszanie, co wskazuje na trudności w realizacji polityki regionalnej, która w swoim założeniu powinna zwiększać spójność międzyregionalną i prowadzić do niwelowania kontrastów w rozwoju poszczególnych regionów.

- Obliczone wskaźniki zróżnicowania działowego przemysłu w Polsce wskazują na utrzymanie średniego zróżnicowania działalności przemysłowej, choć należy podkreślić, że w większości krajów UE zróżnicowanie to jest mniejsze niż w Polsce.

- Przemiany struktury działowej przemysłu w Polsce prowadzą w kierunku upodobnienia się tej struktury do wysokorozwiniętych państw UE, takich jak Francja czy Wielka Brytania, co z punktu widzenia realizacji celów transformacji gospodarczej należy ocenić jako zjawisko bardzo korzystne.

- Na tle innych krajów Polska charakteryzuje się stosunkowo niskim udziałem w zatrudnieniu i wartości dodanej brutto zaawansowanych technologiczne działów przemysłu, co może mieć związek z niekorzystnymi tendencjami zmian w Polsce w zakresie zatrudnienia i nakładów na prace $\mathrm{B}+\mathrm{R}$ na tle innych krajów UE. 


\section{Spatial and division structure of Polish industry against the European Union in the twentieth anniversary of the start of the transformation processes}

The aim of the paper is to analyze the changing role of industry in the Polish economy in the period of economic transformation and European integration based on its share of the employment structure and gross valued added, to determine changes in the spatial structure of Polish industry in the regions (voivodships) and changes in the divisions structure of Polish industry as an expression of restructuring processes. The paper also reviews changes in labour productivity in industry by voidodships, as an expression of modernity of industry and regional competitiveness in attracting industrial investment. The analysis of the similarity of divisions structures of industries in Poland in relation to other EU countries led to the conclusion that this structure increasingly becomes similar to most developed European countries.

\section{Literatura}

Balcerowicz L., 1997, Socjalizm - kapitalizm - transformacja. Szkice z przełomu epok, Wydawnictwo Naukowe PWN, Warszawa.

Borowiec M., 2009, Rola edukacji w kształtowaniu społeczeństwa informacyjnego, [w:] Rola przedsiębiorczości w ksztaltowaniu społeczeństwa informacyjnego, red. Z. Zioło, T. Rachwał, Przedsiębiorczość-Edukacja, nr 5, Zakład Przedsiębiorczości i Gospodarki Przestrzennej IG UP, Wydawnictwo Nowa Era, Warszawa-Kraków, s. 37-47.

Borowiec M., Dorocki S., Jenner B., 2009, Wptyw zasobów kapitatu ludzkiego na ksztaltowanie się społeczeństwa informacyjnego i innowacyjności struktur przemysłowych, [w:] Funkcje przemystu $w$ ksztaltowaniu społeczeństwa informacyjnego, red. Z. Zioło, T. Rachwał, Prace Komisji Geografii Przemysłu PTG nr 13, Wydawnictwo Naukowe Uniwersytetu Pedagogicznego, Warszawa-Kraków, s. 95-109.

Bożyk P., 1999, 24 kraje Europy Środkowej i Wschodniej. Transformacja, SGH, Warszawa.

Domański B., 2003, Industrial change and foreign direct investment in the postsocialist economy: the case of Poland, European and Regional Studies, 10 (2), s. 99-118.

Domański B., 2006, Polski przemyst na tle przemystu Europy Środkowej i Wschodniej, [w:] Międzynarodowe uwarunkowania rozwoju przemystu, red. Z. Zioło, T. Rachwał, Prace Komisji Geografii Przemysłu PTG nr 8, Wydawnictwo Naukowe Akademii Pedagogicznej, Warszawa-Kraków, s. 27-36.

Domański, B., Gwosdz, K., 2008, Efekty mnożnikowe w rozwoju lokalnym i regionalnym, [w:] Region społeczno-ekonomiczny i rozwój regionalny, red. T. Stryjakiewicz, J.J. Parysek, Bogucki Wydawnictwo Naukowe, Poznań, s. 217-235.

Gierańczyk W., 2009, Innowacyjność jako główny filar społeczeństwa informacyjnego Europy, [w:] Funkcje przemystu $w$ ksztaltowaniu społeczeństwa informacyjnego, red. Z. Zioło, T. Rachwał, Prace Komisji Geografii Przemysłu PTG nr 13, Wydawnictwo Naukowe Uniwersytetu Pedagogicznego, Warszawa-Kraków, s. 82-94.

Karpiński A., 2008, Przemiany strukturalne w procesie transformacji Polski 1989-2003-2025, SGH, Warszawa.

Kilar W., 2009, Zróżnicowanie potencjału ekonomicznego światowych korporacji informatycznych, [w:] Funkcje przemystu w ksztaltowaniu społeczeństwa informacyjnego, red. Z. Zioło, T. Rachwał, Prace Komisji Geografii Przemysłu PTG nr 13, Wydawnictwo Naukowe Uniwersytetu Pedagogicznego, Warszawa-Kraków, s. 110-121.

Kołodko G., 1999, Od szoku do terapii. Ekonomia i polityka transformacji, Poltext, Warszawa. 
Kornai J., 1997, Struggle and hope: essays on stabilization and reform in a postsocialist economy, Edward Elgar, Cheltenham.

Koźmiński A.K., 1998, Odrabianie zaległości. Zmiany w organizacji i zarzqdzania w bylym bloku socjalistycznym, Wydawnictwo Naukowe PWN, Warszawa.

Łukawer E., 1994a, Transformacja systemowa w Polsce w oczach ekonomistów, cz. I, Gospodarka Narodowa, $\mathrm{nr} 1$ (48), s. 18-23.

Łukawer E., 1994b, Transformacja systemowa w Polsce w oczach ekonomistów, cz. II, Gospodarka Narodowa, nr 2 (49), s. 17-21.

Rachwał T., 2006, Efekty restrukturyzacji wybranych przedsiębiorstw przemystowych Polski poludniowo-wschodniej, [w:] Efekty restrukturyzacji polskiej przestrzeni przemysłowej, red. Z. Zioło, T. Rachwał, Prace Komisji Geografii Przemysłu PTG nr 9, Wydawnictwo Naukowe Akademii Pedagogicznej, Warszawa-Kraków, s. 98-115.

Rachwał T., 2008, Problematyka badawcza funkcjonowania przedsiębiorstw przemystowych, [w:] Problematyka badawcza geografii przemystu, red. Z. Zioło, T. Rachwał, Prace Komisji Geografii Przemysłu PTG nr 11, Komisja Geografii Przemysłu PTG, Wydawnictwo Naukowe Akademii Pedagogicznej w Krakowie, Warszawa-Kraków, s. 53-85.

Rachwał T., 2009, Changes of Industry in the Countries of Central and Eastern Europe under Conditions of Economic Transformation and European Integration, [w:] Countries of Central \& Eastern Europe Versus Global Economic Crisis, red. J. Kitowski, Geopolitical Studies vol. 15, Wyd. Instytut Geografii i Przestrzennego Zagospodarowania PAN, Warszawa, s. 133-164.

Rachwał T., Wiedermann K., 2008, Multiplier effects in regional development: The case of the motor vehicle industry in Silesian voivodeship (Poland), Quaestiones Geographicae, Series B, Human Geography and Spatial Management, 27B/1, Wydawnictwo Naukowe Uniwersytetu im. Adama Mickiewicza, Poznań, p. 67-80.

Rachwał T., Wiedermann K., Kilar W., 2008a, Wydajność i koszty pracy jako czynniki konkurencyjności przemystu regionów Polski w Unii Europejskiej w ujęciu regionalnym, [w:] Przeksztatcenia regionalnych struktur funkcjonalno-przestrzennych „Europa bez granic - nowe wyzwania”, red. D. Ilnicki, K. Janc, Rozprawy Naukowe Instytutu Geografii i Rozwoju Regionalnego Uniwersytetu Wrocławskiego 3, Instytut Geografii i Rozwoju Regionalnego, UW, Wrocław, s. 79-89.

Rachwał T., Wiedermann K., Kilar W., 2008b, Zmiany potencjału przemystowego województw Polski wschodniej na tle regionów Unii Europejskiej, [w:] Przyrodniczo-ekonomiczny potencjat regionów na pograniczu polsko-ukraińskim, red. R. Fedan, Z. Makieła, Państwowa Wyższa Szkoła Zawodowa im. ks. Bronisława Markiewicza w Jarosławiu, Stowarzyszenie Instytut Polsko-Ukraiński, Jarosław, s. 287-306.

Rachwał T., Wiedermann K., Kilar W., 2009, Rola przemystu w gospodarce uktadów regionalnych Unii Europejskiej, [w:] Problemy ksztaltowania się przestrzennych struktur przemystowych i ich otoczenia, red. Z. Zioło, T. Rachwał, Prace Komisji Geografii Przemysłu PTG nr 14, Wydawnictwo Naukowe Uniwersytetu Pedagogicznego, Warszawa-Kraków, s. 31-42.

Raczyk A., Dobrowolska-Kaniewska H., 2009, Kształtowanie struktur przestrzennych sektora przemystu i ustug wedtug poziomów techniki na przyktadzie województwa dolnoślaskiego, [w:] Funkcje przemystu $w$ ksztaltowaniu społeczeństwa informacyjnego, red. Z. Zioło, T. Rachwał, Prace Komisji Geografii Przemysłu PTG nr 13, Wydawnictwo Naukowe Uniwersytetu Pedagogicznego, Warszawa-Kraków, s. 42-55.

Rosati D.K., 1998, Polska droga do rynku, Polskie Wydawnictwo Ekonomiczne, Warszawa.

Stryjakiewicz T., 1999, Adaptacja przestrzenna przemystu $w$ Polsce $w$ warunkach transformacji, Wydawnictwo Naukowe UAM, Poznań.

Świdurska A., 2009, Kształtowanie się przemystu wysokiej techniki w Polsce, [w:] Funkcje przemystu w ksztaltowaniu społeczeństwa informacyjnego, red. Z. Zioło, T. Rachwał, Prace Komisji Geografii Przemysłu PTG nr 13, Wydawnictwo Naukowe Uniwersytetu Pedagogicznego, Warszawa-Kraków, s. 56-67. 
Troc M., 1991, Ćwiczenia z geografii przemystu, Wydawnictwo Naukowe Wyższej Szkoły Pedagogicznej, Kraków.

Van Zon H., 1996, The Future of Industry in Central and Eastern Europe, Avebury, Aldershot.

Wiedermann K., 2007, Regionalne efekty mnożnikowe rozwoju przemyslu motoryzacyjnego w aktywizacji gospodarczej województwa ślaskiego, [w:] Rola przedsiębiorczości w aktywizacji gospodarczej, red. Z. Zioło, T. Rachwał, Przedsiębiorczość-Edukacja nr 3, Zakład Przedsiębiorczości i Gospodarki Przestrzennej IG AP, Wydawnictwo Nowa Era, Warszawa-Kraków, s. 24-34.

Wiedermann K., 2008, Koncepcja efektów mnożnikowych w wyznaczaniu wplywu przedsiębiorstw na otoczenie spoleczno-gospodarcze, [w:] Problematyka badawcza geografii przemystu, red. Z. Zioło, T. Rachwał, Prace Komisji Geografii Przemysłu PTG nr 11, Wydawnictwo Naukowe Akademii Pedagogicznej, Warszawa-Kraków, s. 98-106.

Wojtyna A., 1994, Polityka przemystowa a instytucjonalne ramy restrukturyzacji w Polsce, Gospodarka Narodowa, nr 12 (56), s. 6-14.

Zioło Z., 1972, Próba konstrukcji miernika syntetycznego w zastosowaniu do badań przemystu, Komisja Nauk Geograficznych, Sprawozdania z posiedzeń Komisji Naukowych PAN Oddział w Krakowie, t. XV/1, Kraków, s. 191-194.

Zioło Z., 1973, Analiza struktury przestrzennej i form koncentracji przemystu województwa rzeszowskiego w świetle wybranych mierników, Folia Geographica, Series: Geographica-Oeconomica, vol. VI, s. 95-116.

Zioło Z., 1996, Oddziaływanie procesów transformacji gospodarki narodowej na funkcjonowanie jednostek gospodarczych, [w:] Wpływ procesów transformacji gospodarki narodowej na funkcjonowanie jednostek gospodarczych i układów przestrzennych, red. Z. Zioło, Komisja Geografii Przemysłu PTG, Instytut Geografii WSP w Krakowie, Warszawa-Kraków, s. 146-151.

Zioło Z., 2009, Procesy ksztaltowania się światowych korporacji i ich wptyw na otoczenie, [w:] Wplyw procesów globalizacji i integracji europejskiej na transformacje struktur przemystowych, red. Z. Zioło, T. Rachwał, Prace Komisji Geografii Przemysłu PTG nr 12, Wydawnictwo Naukowe Uniwersytetu Pedagogicznego, Warszawa-Kraków, s. 11-32.

dr Tomasz Rachwał

Uniwersytet Pedagogiczny im. Komisji Edukacji Narodowej w Krakowie

Instytut Geografii

Zakład Przedsiębiorczości i Gospodarki Przestrzennej

e-mail: t.rachwal@up.krakow.pl 